\title{
Purification and characterization of a surfactant-compatible lipase from Aspergillus tamarii JGIF06 exhibiting energy-efficient removal of oil stains from polycotton fabric
}

\author{
Arijit Das $^{1} \cdot$ Srividya Shivakumar $^{1} \cdot$ Sourav Bhattacharya $^{1} \cdot$ Sujina Shakya $^{1} \cdot$ \\ S. S. Swathi ${ }^{1}$
}

Received: 20 April 2016/ Accepted: 31 May 2016/Published online: 10 June 2016

(c) The Author(s) 2016. This article is published with open access at Springerlink.com

\begin{abstract}
An extracellular lipase with 23,666.66 U/ml/min activity was produced by Aspergillus tamarii JGIF06 under submerged fermentation in mineral salt medium containing coconut oil $(2.5 \% \mathrm{v} / \mathrm{v})$, tryptone $(2 \% \mathrm{w} / \mathrm{v})$ and ammonium chloride $(2 \% \mathrm{w} / \mathrm{v})$, with initial $\mathrm{pH}$ of $5 \pm 0.2$, incubated at $25^{\circ} \mathrm{C}$ for 7 days on a rotary shaker at $120 \mathrm{rpm}$. A 7.9-fold increase in lipase-specific activity was recorded after purification by DEAE Sepharose ion exchange and Sephadex G200 column chromatography. The apparent molecular mass of this enzyme was revealed as $50 \mathrm{kDa}$ by sodium dodecyl sulphate polyacrylamide gel electrophoresis. The optimal lipase activity was recorded at $\mathrm{pH} 4$ and $37^{\circ} \mathrm{C}$. The enzyme revealed broad specificity towards different vegetable oils. The $K_{m}$ and $V_{\max }$ of the lipase on olive oil was found to be $330.4 \mathrm{mg}$ and 53,690 U/ $\mathrm{ml} / \mathrm{min}$, respectively. The lipase activity was stable in the presence of surfactants such as cetrimonium bromide, sodium dodecyl sulphate and Tween 80 , and metal ions and reagents such as $\mathrm{Ca}^{2+}, \mathrm{Ba}^{2+}$ and 2-mercaptoethanol. However, the activity was greatly reduced in the presence of organic solvents such as chloroform. The stain removal potential of the crude lipase was determined on polycotton fabric pieces stained with peanut oil. Lipase added to cold water alone significantly enhanced the removal of stain by $152 \%$. The addition of lipase also improved the stain removal efficiency of a commercially available detergent in the presence of either cold $\left(25 \pm 2{ }^{\circ} \mathrm{C}\right)$ or hot $\left(65 \pm 2{ }^{\circ} \mathrm{C}\right)$
\end{abstract}

Arijit Das

jit2007das@gmail.com

1 Department of Microbiology, Center for Post Graduate Studies, Jain University, 18/3, 9th Main, Jayanagar, 3rd Block, Bangalore 560011, Karnataka, India water. The current findings suggest the potentiality of this enzyme for energy-efficient biocatalytic application.

Keywords Aspergillus tamarii · Lipase · Vegetable oil · Surfactant

\section{Introduction}

Lipases (triacylglycerol acylhydrolases, EC 3.1.1.3) are enzymes that catalyse the hydrolysis of triacylglycerol to glycerol and free fatty acids (Sharma and Kanwar 2014). Lipases from microorganisms are considered better than those obtained from plants or animals because of faster production, higher yields and greater stability. The enzyme production can be enhanced by selection of potent strains, genetic manipulation and optimization of growth conditions (Dayanandan et al. 2013).

High production cost of lipase is a major hurdle in its application in industrial processes. Therefore, various attempts have been made to lower the cost of its production (Smaniotto et al. 2012). Fungi are usually preferred as lipase producers because they synthesize extracellular enzymes that can be easily extracted from the production media (Maia et al. 1999). However, the synthesis of fungal lipases is governed by both nutritional and physico-chemical parameters such as $\mathrm{pH}$, temperature and level of dissolved oxygen.

Some of the applications of lipases include synthesis of organic chemicals, flavour enhancement during cheese production and treatment of high fat-containing waste water (Sharma et al. 2001). Fungal lipases are extensively used in the detergent industries for removal of tough oily stains from fabrics. Rapid degradation of oils with better specificity even under mild conditions has made these 
enzymes useful in the formulation of soaps and production of biosurfactants (Gopinath et al. 2003). However, very few studies which discuss the characterization of surfactant-compatible fungal lipases are available. A detailed analysis of lipase properties facilitates its application in relevant industrial processes (Borrelli and Trono 2015). Owing to the continuous demand for fungal lipases in various industrial sectors, the present study was undertaken with the objectives of purification, characterization and determination of the oil-destaining potential of lipase from a selected fungal isolate.

\section{Materials and methods}

\section{Source of fungal strain, substrates and chemicals}

A lipolytic fungal strain, isolated from rhizospheric soil, was obtained from the Department of Microbiology, Center for Post Graduate Studies, Jain University, Bangalore, India. The lipolytic activity was monitored by observing a deep blue colour around the fungal colony on Spirit blue agar. The fungal isolate was identified as Aspergillus tamarii JGIF06 (GenBank Accession No. KR259959) by partial 18S rDNA sequencing at Chromous Biotech Pvt. Ltd., Bangalore, India. Pure culture of the fungus was maintained on potato dextrose agar slants and stored at $4{ }^{\circ} \mathrm{C}$ until use. All the analytical-grade chemicals and reagents were procured from HiMedia Laboratories Pvt. Ltd., Mumbai, India. The edible-grade vegetable oils and detergent powder were purchased from provisional stores in Bangalore, India.

\section{Production of lipase}

Lipase production was carried out in $1000 \mathrm{ml}$ Erlenmeyer flask containing $500 \mathrm{ml}$ of supplemented mineral salts medium containing (g/l) tryptone, $20 ; \mathrm{NH}_{4} \mathrm{Cl}, 20 ; \mathrm{K}_{2} \mathrm{HPO}_{4}$, $3 ; \mathrm{KH}_{2} \mathrm{PO}_{4}, 1 ; \mathrm{MgSO}_{4}, 0.1 ; \mathrm{MgCl}_{2}, 0.12$; cetrimonium bromide (CTAB), $0.5 \%$ (w/v); coconut oil, $2.5 \%(\mathrm{v} / \mathrm{v})$ and distilled water, adjusted to an initial $\mathrm{pH}$ of $5 \pm 0.2$ and autoclaved. The sterile medium was aseptically inoculated with $1.5 \%(\mathrm{v} / \mathrm{v})$ fungal conidial suspension prepared in mineral salt solution and incubated at $25{ }^{\circ} \mathrm{C}$ for 7 days on a rotary shaker at $120 \mathrm{rpm}$. Post-incubation, the fungal broth was filtered using Whatman's No. 1 filter paper and centrifuged at $5000 \mathrm{rpm}$ for $30 \mathrm{~min}$ at $4{ }^{\circ} \mathrm{C}$. The clear supernatant was subjected to lipase assay and further purification.

\section{Lipase assay}

The enzymatic assay of lipase was performed by the titrimetric method using olive oil as the substrate and thymolphthalein as the indicator (Padhiar et al. 2011). The end point was determined by the change in the colour of the reaction mixture from colourless to pale blue. One unit of enzyme activity $(\mathrm{U})$ was defined as $\mu \mathrm{mol}$ of free fatty acids released due to enzyme action and expressed as $\mathrm{U} / \mathrm{ml} / \mathrm{min}$.

\section{Protein estimation}

The protein content was evaluated using the method of Lowry et al. (1951) with $200 \mu \mathrm{g} / \mathrm{ml}$ of crystalline bovine serum albumin fraction $\mathrm{V}$ as the standard.

\section{Purification of lipase}

The chilled clear supernatant containing crude lipase was subjected to ammonium sulphate precipitation till $80 \%$ saturation was attained at $4{ }^{\circ} \mathrm{C}$. The resulting precipitate was centrifuged at $5000 \mathrm{rpm}$ for $30 \mathrm{~min}$ at $4{ }^{\circ} \mathrm{C}$ and resuspended in a minimum volume of $0.1 \mathrm{M}$ phosphate buffer ( $\mathrm{pH} 6)$ at $4{ }^{\circ} \mathrm{C}$. The enzyme solution was dialysed using dialysis membrane 50 (Himedia, Mumbai, India) against $0.01 \mathrm{M}$ phosphate buffer ( $\mathrm{pH}$ 6) at $4{ }^{\circ} \mathrm{C}$ overnight. The dialysed enzyme was loaded onto DEAE Sepharose column $(2 \times 10 \mathrm{~cm})$ pre-equilibrated with $20 \mathrm{mM}$ Tris- $\mathrm{HCl}$ buffer ( $\mathrm{pH} \mathrm{6)}$ and eluted with a linear gradient of $(0-200 \mathrm{mM}) \mathrm{NaCl}$ in the same buffer at a flow rate of $0.5 \mathrm{ml} / \mathrm{min}$. The eluted fractions showing lipase activity were pooled and applied to Sephadex G200 column $(2 \times 20 \mathrm{~cm})$ pre-equilibrated with $20 \mathrm{mM}$ Tris-HCl buffer $(\mathrm{pH} 6)$ at a flow rate of $0.5 \mathrm{ml} / \mathrm{min}$. Fractions showing lipase activity were pooled and stored at $4{ }^{\circ} \mathrm{C}$.

\section{Determination of molecular mass}

The relative molecular mass of the purified lipase was determined by SDS-PAGE in a Mini Protean Tetra cell vertical electrophoresis unit (Bio-Rad) using a $10 \%(\mathrm{w} / \mathrm{v})$ acrylamide gel, following the method described by Laemmli (1970). Lipase samples (crude and purified) were analysed after staining with Coomassie Brilliant Blue R-250 and molecular mass was estimated with reference to medium range molecular weight protein marker (Genei, Bangalore, India).

\section{Zymography}

After non-denaturing PAGE with the purified lipase, the gel was placed onto a pre-solidified plate containing $3 \%$ (v/v) olive oil and $0.001 \%(\mathrm{w} / \mathrm{v})$ Rhodamine B in $2 \%(\mathrm{w} /$ v) agarose gel. After overnight incubation at $27 \pm 2{ }^{\circ} \mathrm{C}$, in situ lipase activity was detected as a fluorescent band under $350 \mathrm{~nm}$ UV light (Castro-Ochoa et al. 2005). 


\section{Characterization of lipase}

The optimum $\mathrm{pH}$ for lipase activity was measured using olive oil as the substrate, at $27{ }^{\circ} \mathrm{C}$ in buffers $(200 \mathrm{mM})$ of different $\mathrm{pH}$ values such as citrate buffer $(\mathrm{pH} 3.0-5.0$ ), phosphate buffer ( $\mathrm{pH}$ 6.0-8.0) and glycine- $\mathrm{NaOH}$ buffer (pH 9.0-10.0). The optimum temperature for the lipase activity was determined at different temperatures $(4,27$, $37,45,60,80$ and $100{ }^{\circ} \mathrm{C}$ ) using $200 \mathrm{mM}$ citrate buffer of $\mathrm{pH}$ 4. Lipase substrate specificity was analysed using different vegetable oils (coconut oil, peanut oil, sesame oil, sunflower oil, soybean oil and olive oil). The effect of substrate concentration on lipase activity was evaluated by incubating $1 \mathrm{ml}$ of the enzyme with varying concentrations $\left(460-9200 \mathrm{mg}\right.$ ) of substrate (olive oil) at $37{ }^{\circ} \mathrm{C} . K_{m}$ and $V_{\max }$ values were calculated from Lineweaver-Burk plot using Hyper32 software.

The effect of surfactants on lipase activity was analysed after pre-incubating the enzyme for $15 \mathrm{~min}$ at $37{ }^{\circ} \mathrm{C}$ with $1 \%$ concentration of detergents such as Triton X-100, Tween 80 , Tween 20, CTAB or sodium dodecyl sulphate (SDS). The effect of diverse chemicals on lipase activity was determined after pre-incubation of the enzyme for $15 \mathrm{~min}$ at $37{ }^{\circ} \mathrm{C}$ with $10 \mathrm{mM}$ concentration of $\mathrm{CaCl}_{2}$, $\mathrm{MgCl}_{2}, \mathrm{MnCl}_{2}, \mathrm{ZnCl}_{2}, \mathrm{BaCl}_{2}, \mathrm{HgCl}_{2}$, EDTA or 2-mercaptoethanol. The effect of organic solvents on lipase activity was determined after pre-incubation of the enzyme $(0.2 \mathrm{ml})$ for $15 \mathrm{~min}$ at $37^{\circ} \mathrm{C}$ in $0.5 \mathrm{ml}$ of methanol, ethanol, 2-propanol, acetone or chloroform (Castro-Ochoa et al. 2005). Suitable controls were also maintained without the addition of any surfactant, metal salt or solvent. The residual activity was measured by titrimetric assay and expressed as percentage.

\section{Determination of oil-destaining efficiency}

The crude fungal lipase was tested for its ability to remove oil stains from fabrics. Polycotton fabric was cut into pieces $(3 \mathrm{~cm} \times 2 \mathrm{~cm})$ and each piece was stained with two drops of peanut oil used for deep frying. The fabric pieces were allowed to dry and subjected to various oil-destaining treatments such as plain water; water and commercially available detergent $1 \%(\mathrm{w} / \mathrm{v})$; water and lipase; water, lipase and detergent. Each of these treatments was studied using cold $\left(25 \pm 2{ }^{\circ} \mathrm{C}\right)$ or hot $\left(65 \pm 2{ }^{\circ} \mathrm{C}\right)$ water separately. The oil-stained fabric pieces were separately soaked in each treatment solution taken in a $100 \mathrm{ml}$ Erlenmeyer flask and gently agitated. Post-incubation for $30 \mathrm{~min}$, the fabric pieces were removed, dried and observed for residual oil stains. The efficiency of lipolytic activity was evaluated by the lipase titrimetric assay estimating the amount of free fatty acids released during each treatment.

\section{Statistical analysis}

Lipase characterization was conducted in triplicate and the data have been graphically presented as mean \pm standard deviation (SD) $(n=3)$. Oil-destaining studies were conducted in triplicate and the data were analysed by two-way Analysis of Variance (ANOVA) using GraphPad Prism version 6.

\section{Results and discussion}

\section{Lipase production by $A$. tamarii JGIF06}

Based on the results of media optimization (data not shown), lipase production by the lipolytic fungus $A$. tamarii JGIF06 was carried out using mineral salt medium supplemented with coconut oil, tryptone and $\mathrm{NH}_{4} \mathrm{Cl}$. A high lipase activity $(23,666.66 \mathrm{U} / \mathrm{ml} / \mathrm{min})$ was recorded in the culture filtrate. The positive impact of coconut oil on lipase production by A. tamarii JGIF06 might be attributed to its high content $(92 \%)$ of saturated fatty acids (primarily triglycerides). About $70 \%$ of these are short- and mediumchain saturated fatty acids (Ribeiro et al. 2011). The shortand medium-chain fatty acids are utilized by fungi through the carnitine-independent transport system (Hynes et al. 2006; Son et al. 2012). Khoramnia et al. (2013) also reported maximum lipolytic activity from Geotrichum candidum when coconut oil was used as the substrate.

A combination of organic (tryptone) and inorganic $\left(\mathrm{NH}_{4} \mathrm{Cl}\right)$ nitrogen supplements in the production medium facilitated a high yield of lipase. This might be due to faster assimilation of inorganic nitrogen source by the fungal mycelia and enrichment of the production medium with several growth factors and amino acids derived from the organic nitrogen source. The current finding is in agreement with Bindiya and Ramana (2012) who reported that among various inorganic sources, $\mathrm{NH}_{4} \mathrm{Cl}$ supplementation showed the best lipase production from olive oil by Aspergillus sydowii.

Incorporation of cationic surfactant CTAB in the medium probably altered the cell permeability, thereby enhancing the enzyme secretion. A similar result was reported by Polizelli et al. (2008), who observed that the activity of lipase from Pachira aquatica was significantly enhanced in the presence of CTAB.

\section{Purification of lipase}

The crude fungal lipase obtained by filtration of the fungal broth was clarified by centrifugation. The clear supernatant was concentrated by ammonium sulphate precipitation and desalted by dialysis. The partially purified enzyme showed a 3.4-fold increase in specific activity in comparison to the

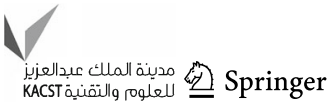


crude lipase, with a $50.7 \%$ recovery. This was purified by DEAE Sepharose ion exchange chromatography and Sephadex G200 gel filtration chromatography. The purification steps resulted in a 7.9-fold increase in specific activity; however, the final recovery was $43.1 \%$. The purification profile of the fungal lipase is shown in Table 1 .

\section{Molecular mass of lipase and zymography}

The SDS-PAGE profile of crude lipase demonstrated multiple bands with relative molecular masses ranging between 25 and $62 \mathrm{kDa}$, whereas the purified lipase showed a single protein band, indicating that the apparent molecular mass is $\sim 50 \mathrm{kDa}$ (Fig. 1a). This is in close proximity with that reported by Padhiar et al. (2011), wherein an extracellular lipase from Aspergillus flavus showed an apparent molecular mass of $47 \mathrm{kDa}$. Ulker and Karaoğlu (2012) reported the production of an extracellular lipase from Mucor hiemalis f. corticola having a molecular mass of $46 \mathrm{kDa}$. Zymography was performed with the purified lipase using a non-denaturing gel. The gel was placed on agarose plate containing olive oil and Rhodamine B. When irradiated with UV light $(350 \mathrm{~nm})$, a clear orange band was observed which indicated lipolytic activity (Fig. 1b).

\section{Characterization of lipase}

\section{Effect of $\mathrm{pH}$}

Enzymes are most active at their optimum $\mathrm{pH}$, as their active sites have maximum interaction with the substrate. Any drastic change in the $\mathrm{pH}$ of a medium leads to denaturation of the enzyme resulting in the loss of its activity. Although the lipase from A. tamarii JGIF06 was active over a wide range of $\mathrm{pH}$ ranging from 3 to 9, maximum activity $(37,500 \mathrm{U} / \mathrm{ml} / \mathrm{min})$ was recorded at $\mathrm{pH}$ 4 (Fig. 2a). At pH 10, the activity of the enzyme slightly decreased. Hiol et al. (1999) had reported that the lipase produced by Mucor hiemalis $f$. hiemalis was stable for $15 \mathrm{~min}$ in the $\mathrm{pH}$ range of $4-9$.

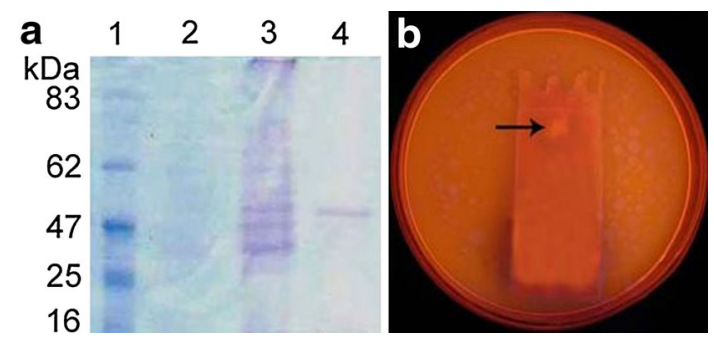

Fig. 1 a SDS-PAGE profile of lipase from A. tamarii JGIF06. 1 Protein marker. 2 Uninoculated medium. 3 Crude lipase extract. 4 Purified lipase. The molecular sizes of the marker proteins are shown on the left. b Zymography of purified lipase showing a band of lipolysis (indicated by arrow) on visualization of gel under $350 \mathrm{~nm}$ UV light

\section{Effect of temperature}

Temperature plays a pivotal role in determining the activity of enzymes. $37{ }^{\circ} \mathrm{C}$ was found to be the optimum temperature for lipase activity $(88,166.66 \mathrm{U} / \mathrm{ml} / \mathrm{min})$. Thereafter, an increase in temperature showed a gradual decline in the enzyme activity (Fig. 2b). The probable reason for this decrease might be due to the disruption of the tertiary structure of lipase which would have altered the configuration of the active site, thereby decreasing the enzyme substrate interaction. The enzyme retained 63 and $50 \%$ of its activity at 45 and $60{ }^{\circ} \mathrm{C}$, respectively. The current finding is supported by Hiol et al. (2000) who observed that the optimum temperature for activity of a lipase from Rhizopus oryzae was $35{ }^{\circ} \mathrm{C}$, and $65 \%$ of its activity was retained after $30 \mathrm{~min}$ of incubation at $45^{\circ} \mathrm{C}$.

\section{Substrate specificity of the lipase}

Six different vegetable oils were analysed for determining the substrate specificity of the lipase. Among these, maximum lipase activity was revealed with peanut oil $(48,333.33 \mathrm{U} / \mathrm{ml} / \mathrm{min})$ followed by sesame oil and coconut oil (Fig. 3a). The results of substrate specificity clearly indicated the versatile ability of this fungal lipase to act on different vegetable oils with moderately high contents of unsaturated fatty acids $(75-80 \%$ in sesame and peanut

Table 1 Purification profile of lipase from A. tamarii JGIF06

\begin{tabular}{lllccc}
\hline Purification step & Total protein $(\mathrm{mg})$ & $\begin{array}{l}\text { Total activity } \\
(\mathrm{U} / \mathrm{ml} / \mathrm{min})\end{array}$ & $\begin{array}{l}\text { Specific activity } \\
(\mathrm{U} / \mathrm{mg})\end{array}$ & Recovery (\%) & Purification fold \\
\hline Crude enzyme filtrate & 0.71852 & $23,666.66$ & $32,938.06$ & 100 & 1 \\
Ammonium sulphate precipitated fraction & 0.26666 & $23,166.66$ & $86,877.14$ & 97.8 & 2.6 \\
Dialysed fraction & 0.10741 & $12,016.66$ & $111,876.54$ & 50.7 & 3.4 \\
DEAE Sepharose and Sephadex G200 & 0.03920 & $10,200.25$ & $260,210.46$ & 43.1 & 7.9 \\
\hline
\end{tabular}



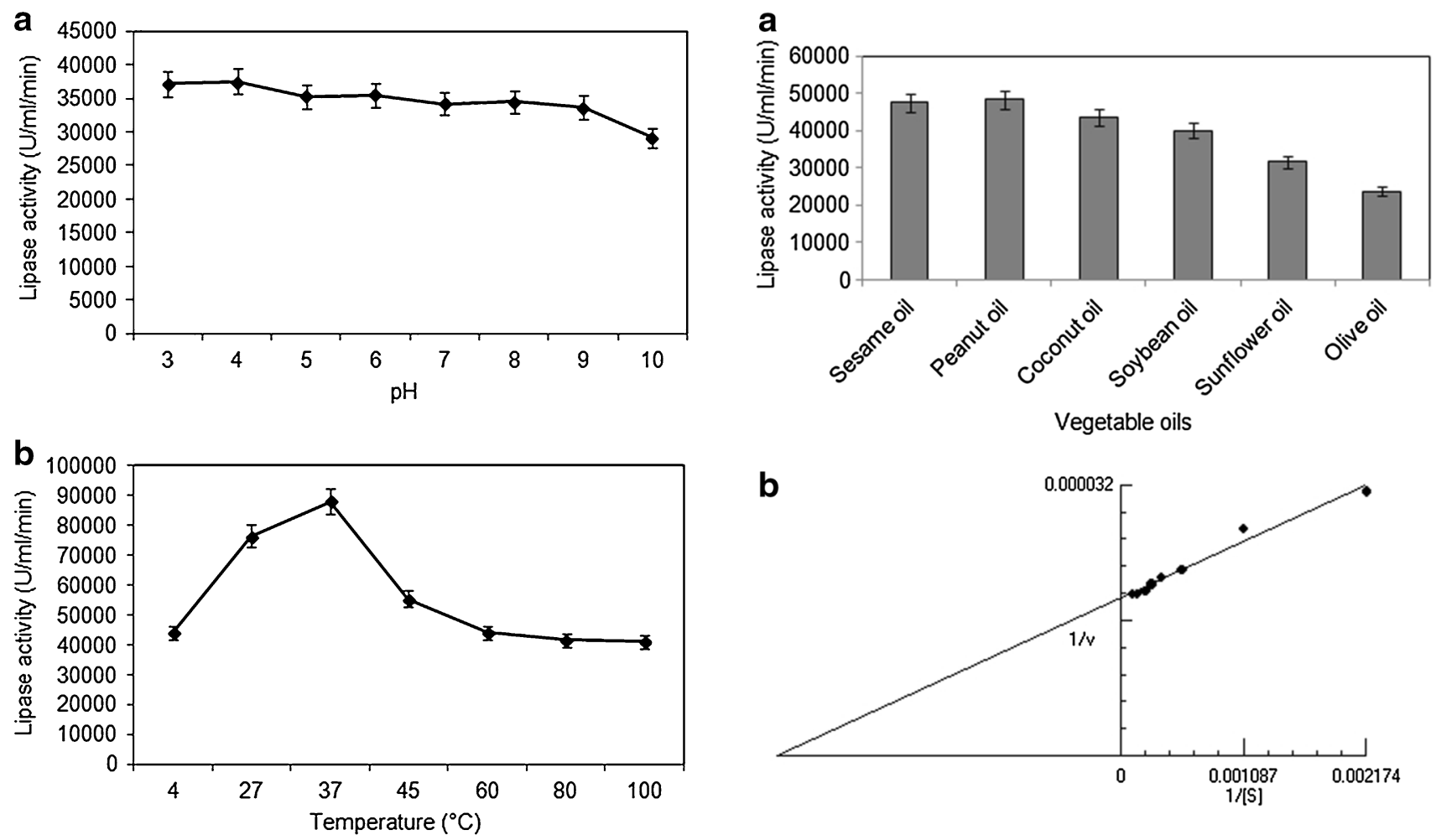

Fig. 2 a Effect of pH on lipase activity. b Effect of temperature on lipase activity. Data represent mean $\pm \mathrm{SD}(n=3) ; p<0.05$

oils) as well as those with very high content of saturated fatty acids ( $86 \%$ in coconut oil). A study conducted by Rahman et al. (2006) reported that the lipase produced by Pseudomonas sp. strain S5 had more affinity towards longcarbon chain natural oils like olive oil, groundnut oil, sesame oil and coconut oil. However, Cihangir and Sarikaya (2004) reported that an isolate of Aspergillus sp. showed better lipase activity when olive oil was used as the substrate.

\section{Effect of substrate concentration}

An enzymatic reaction involves the interaction of the active site of an enzyme with its specific substrate. As the substrate concentration increases, the active sites of the enzyme molecules get saturated. Since the standard lipase assay was conducted using olive oil, the effect of substrate concentration on lipase activity was determined through Michaelis-Menten equation and Lineweaver-Burk plot using olive oil as the substrate (Fig. 3b). The $K_{m}$ and $V_{\max }$ of the lipase from A. tamarii JGIF06 were found to be $330.4 \mathrm{mg}$ and 53,690 U/ml/min, respectively. The low $K_{m}$ value indicated that a small quantity of olive oil could saturate the enzyme and therefore the enzyme is specific for the substrate. The $K_{m}$ and $V_{\max }$ of a lipase from psychrotrophic Penicillium chrysogenum $9^{\prime}$ were reported as

Fig. 3 a Specificity of lipase towards different vegetable oils used as substrates. b Lineweaver-Burk plot using olive oil as substrate for the lipase. Data represent mean $\pm \mathrm{SD}(n=3) ; p<0.05$

$2.33 \mathrm{mM}$ and $22.1 \mathrm{U} / \mathrm{ml}$, respectively, using tributyrin as substrate (Bancerz et al. 2005).

\section{Effect of surfactants}

Surfactants usually denature enzymes through disruption of their tertiary structures. The lipase from A. tamarii JGIF06 retained $90.84 \%$ of its activity in the presence of CTAB, while the lowest residual activity was recorded with Tween $20(71.83 \%)$, compared to $100 \%$ activity shown by the control (without any surfactant) (Fig. 4a). The results indicated the potentiality of the lipase to tolerate various surfactants like SDS, CTAB and Tween 80 . The activity of a lipase produced by endophytic fungus Cercospora kikuchii was stable in the presence of surfactants such as Tween 20, Tween 80, SDS and Triton X-100, wherein 98-100\% of enzymatic activity was retained (Costa-Silva et al. 2014).

\section{Effect of salts and reagents}

Enzymes require metal ions as co-factors in various metabolic pathways. The results showed a slight increase in the enzyme activity in the presence of $\mathrm{CaCl}_{2}$, whereas $92 \%$ activity was retained with $\mathrm{BaCl}_{2}$ (Fig. $4 \mathrm{~b}$ ). With the other metal ions, the residual lipase activities ranged 

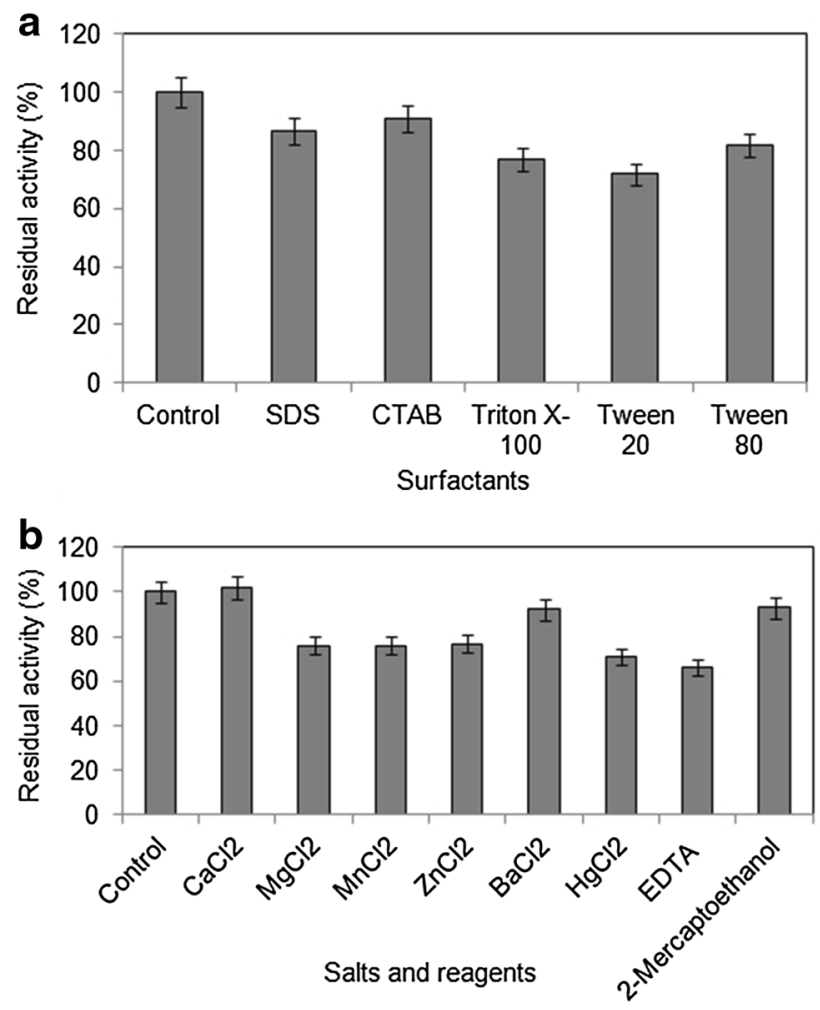

Fig. 4 a Effect of surfactants on lipase activity. b Effect of metal salts and reagents on lipase activity. Data represent mean \pm SD $(n=3) ; p<0.05$

between 71 and $76 \%$. Chartrain et al. (1993) observed that a lipase from $P$. aeruginosa MB 5001 was stimulated (1.24-fold) by adding $10 \mathrm{mM} \mathrm{CaCl}{ }_{2}$, but was strongly inhibited by $1 \mathrm{mM} \mathrm{ZnSO}_{4}$ (94\% inhibition). In this study, the residual lipase activity was minimum $(66.19 \%)$ when pre-incubated in $10 \mathrm{mM}$ EDTA. EDTA probably chelated the metal ions present with the enzyme, thereby denaturing the enzyme. Interestingly, the activity of the lipase was relatively stable in the presence of 2-mercaptoethanol. The resistance of the fungal lipase to 2-mercaptoethanol might indicate the presence of a lesser number of disulphide bonds exposed on the enzyme surface. A similar observation was made by Yadav et al. (1998) who reported that lipase from $A$. terreus was unaffected by 2 -mercaptoethanol and potassium ferrocyanide.

\section{Effect of organic solvents}

Pre-incubation of the fungal lipase with each of the organic solvents showed a drastic reduction in its activity (in the range of $3.5-7.7 \%)$ as compared to the control (100\%). The activity decreased in the following order: 2-propanol $>$ acetone $>$ ethanol $>$ methanol $>$ chloroform. The reduction in lipase activity when incubated with organic solvents might be due to the dehydrating action of organic solvents which would have removed water molecules from the vicinity of the enzyme, thus precipitating the enzyme which adversely affected its activity. In addition, all the organic solvents might have caused denaturation of the amino acid residues present in the enzyme molecule. Hernández-Rodríguez et al. (2009) reported that the activities of lipases from Rhizopus sp. were reduced in the presence of polar solvents like ethanol and $i$-propanol.

\section{Oil-destaining efficiency of the lipase}

Polycotton fabric pieces were stained with peanut oil. Peanut oil is usually preferred for deep frying because it is relatively stable with a high smoke point (Das et al. 2013). This explains the rationale behind the use of peanut oil in the present study to obtain tough stains on the fabric pieces. The oil-stained fabric pieces were subjected to different combinations of lipolytic treatments involving cold or hot water, detergent and lipase. Oil-destaining activity was least for the treatment involving only plain cold water, indicating its inefficiency $(166.66 \mathrm{U} / \mathrm{ml} / \mathrm{min})$ (Fig. 5). Treatment with hot water alone did not promote efficient removal of oil stains. However, an increase in lipolytic activity was recorded when combinations of cold or hot water and detergent were used. Furthermore, even in the absence of detergent, the lipolytic activity was significantly enhanced by 152 and $17.4 \%$ on addition of crude fungal lipase to cold and hot water, respectively. Treatments involving cold or hot water, lipase and detergent showed further enhancement in lipolytic activity, with the highest destaining potential $(29,000 \mathrm{U} / \mathrm{ml} /$ min) recorded with hot water. Following various lipolytic treatments, it was evident that addition of the crude lipase resulted in significant enhancement in stain removal efficiency of a commercially available detergent compared to lower lipolytic activity $(13,000 \mathrm{U} / \mathrm{ml} / \mathrm{min})$ and stain removal capacity of hot water with only detergent. This result clearly indicated the detergent-compatible nature of the fungal

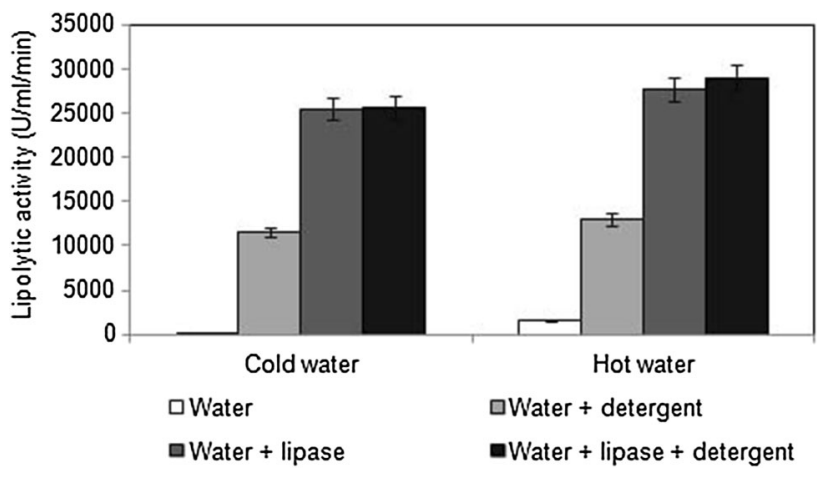

Fig. 5 Oil-destaining efficiency of various lipolytic treatments on oil-stained fabric pieces. Data represent mean $\pm \mathrm{SD} \quad(n=3)$; $p<0.05$ 
lipase. However, the lipolytic activities observed following various treatments with hot water did not reveal any significant difference from those obtained with cold water. It could be interpreted that the crude lipase was effective in removing oil stains even at moderately cold temperature, thereby reducing energy consumption. This indicates the possibility of its application in energy-efficient systems. Hemachander and Puvanakrishnan (2000) had reported that in the presence of a detergent, a lipase produced by Ralstonia pickettii enhanced the removal of oil by 24-27\% compared to treatment with only detergent. In an earlier study, a lipase from Fusarium oxysporum was found compatible with various surfactants and commercial detergents (Prazeres et al. 2006).

\section{Conclusions}

The extracellular lipase produced by A. tamarii JGIF06 exhibited specificity towards a range of saturated and unsaturated vegetable oils. This may indicate its ability to remove a variety of lipid stains from fabric pieces. The stability in the presence of metal ions, surfactants and broad $\mathrm{pH}$ range, together with its lipolytic potential at moderate temperature, suggests the application of this lipase in detergent formulation and energy-efficient biocatalysis.

Acknowledgments The authors would like to thank the management of Jain University, Bangalore, for providing the required financial and infrastructural facilities.

\section{Compliance with ethical standards}

Conflict of interest The authors declare that they have no conflict of interest.

Open Access This article is distributed under the terms of the Creative Commons Attribution 4.0 International License (http:// creativecommons.org/licenses/by/4.0/), which permits unrestricted use, distribution, and reproduction in any medium, provided you give appropriate credit to the original author(s) and the source, provide a link to the Creative Commons license, and indicate if changes were made.

\section{References}

Bancerz R, Ginalska G, Fiedurek J, Gromada A (2005) Cultivation conditions and properties of extracellular crude lipase from the psychrotrophic fungus Penicillium chrysogenum $9^{\prime}$. J Ind Microbiol Biotechnol 32:253-260

Bindiya P, Ramana T (2012) Optimization of lipase production from an indigenously isolated marine Aspergillus sydowii of Bay of Bengal. J Biochem Tech 3:S203-S211

Borrelli GM, Trono D (2015) Recombinant lipases and phospholipases and their use as biocatalysts for industrial applications. Int J Mol Sci 16:20774-20840
Castro-Ochoa LD, Rodriguez-Gomez C, Valerio-Alfaro G, Ros RO (2005) Screening, purification and characterization of the thermoalkalophilic lipase produced by Bacillus thermoleovorans CCR11. Enzym Microb Technol 37:648-654

Chartrain M, Katz L, Marcin C, Thien M, Smith S, Fisher F, Goklen K, Salmon P, Brix T, Price K, Greasham R (1993) Purification and characterization of a novel bioconverting lipase from Pseudomonas aeruginosa MB 5001. Enzym Microb Technol 15:575-580

Cihangir N, Sarikaya E (2004) Investigation of lipase production by a new isolate of Aspergillus sp. World J Microbiol Biotechnol 20:193-197

Costa-Silva TA, Souza CRF, Oliveira WP, Said S (2014) Characterization and spray drying of lipase produced by the endophytic fungus Cercospora kikuchii. Braz J Chem Eng 31:849-858

Das AK, Babylatha R, Pavithra AS, Khatoon S (2013) Thermal degradation of groundnut oil during continuous and intermittent frying. J Food Sci Technol 50:1186-1192

Dayanandan A, Hilda Vimala Rani S, Shanmugavel M, Gnanamani A, Suseela Rajakumar G (2013) Enhanced production of Aspergillus tamarii lipase for recovery of fat from tannery fleshings. Braz J Microbiol 44:1089-1095

Gopinath SCB, Hilda A, Lakshmi Priya T, Annadurai G, Anbu P (2003) Purification of lipase from Geotrichum candidum: conditions optimized for enzyme production using BoxBehnken design. World J Microbiol Biotechnol 19:681-689

Hemachander C, Puvanakrishnan R (2000) Lipase from Ralstonia pickettii as an additive in laundry detergent formulations. Process Biochem 35:809-814

Hernández-Rodríguez B, Córdova J, Bárzana E, Favela-Torres E (2009) Effects of organic solvents on activity and stability of lipases produced by thermotolerant fungi in solid-state fermentation. J Mol Catal B Enzym 61:136-142

Hiol A, Jonzo MD, Druet D, Comeau L (1999) Production, purification and characterization of an extracellular lipase from Mucor hiemalis $f$. hiemalis. Enzym Microb Technol 25:80-87

Hiol A, Jonzo MD, Rugani N, Druet D, Sarda L, Comeau LC (2000) Purification and characterization of an extracellular lipase from a thermophilic Rhizopus oryzae strain isolated from palm fruit. Enzym Microb Technol 26:421-430

Hynes MJ, Murray SL, Duncan A, Khew GS, Davis MA (2006) Regulatory genes controlling fatty acid catabolism and peroxisomal functions in the filamentous fungus Aspergillus nidulans. Eukaryot Cell 5:794-805

Khoramnia A, Ebrahimpour A, Ghanbari R, Ajdari Z, Lai O-M (2013) Improvement of medium chain fatty acid content and antimicrobial activity of coconut oil via solid-state fermentation using a Malaysian Geotrichum candidum. Biomed Res Int 2013:954542

Laemmli UK (1970) Cleavage of structural proteins during the assembly of the head of bacteriophage T4. Nature 227:680-685

Lowry OH, Rosebrough NJ, Farr AL, Randall RJ (1951) Protein measurement with the Folin phenol reagent. J Biol Chem 193:265-275

Maia MMD, de Morais MMC, Morais MA Jr, de Jr M, Melo EHM, Filho JLL (1999) Production of extracellular lipase by the phytopathogenic fungus Fusarium solani FS1. Rev Microbiol 30:304-309

Padhiar J, Das A, Bhattacharya S (2011) Optimization of process parameters influencing the submerged fermentation of extracellular lipases from Pseudomonas aeruginosa, Candida albicans and Aspergillus flavus. Pak J Biol Sci 14:1011-1018

Polizelli PP, Tiera MJ, Bonilla-Rodriguez GO (2008) Effect of surfactants and polyethylene glycol on the activity and stability of a lipase from oilseeds of Pachira aquatica. J Am Oil Chem Soc 85:749-753

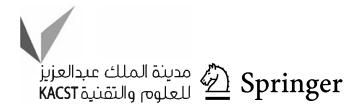


Prazeres JNdos, Cruz JAB, Pastore GM (2006) Characterization of alkaline lipase from Fusarium oxysporum and the effect of different surfactants and detergents on the enzyme activity. Braz J Microbiol 37:505-509

Rahman RN, Baharum SN, Salleh AB, Basri M (2006) S5 Lipase: an organic solvent tolerant enzyme. J Microbiol 44:583-590

Ribeiro BD, de Castro AM, Coelho MAZ, Freire DMG (2011) Production and use of lipases in bioenergy: a review from the feedstocks to biodiesel production. Enzym Res 2011: 615803

Sharma S, Kanwar SS (2014) Organic solvent tolerant lipases and applications. Sci World J 2014:625258

Sharma R, Chisti Y, Banerjee UC (2001) Production, purification, characterization, and applications of lipases. Biotechnol Adv 19:627-662
Smaniotto A, Skovronski A, Rigo E, Tsai SM, Durrer A, Foltran LL, Luccio MD, Oliveira JV, de Oliveira D, Treichel H (2012) Synthetic lipase production from a newly isolated Sporidiobolus pararoseus strain by submerged fermentation. Braz J Microbiol 43:1490-1498

Son H, Min K, Lee J, Choi GJ, Kim J-C, Lee Y-W (2012) Mitochondrial carnitine-dependent acetyl coenzyme a transport is required for normal sexual and asexual development of the ascomycete Gibberella zeae. Eukaryot Cell 11:1143-1153

Ulker S, Karaoğlu SA (2012) Purification and characterization of an extracellular lipase from Mucor hiemalis f. corticola isolated from soil. J Biosci Bioeng 114:385-390

Yadav RP, Saxena RK, Gupta R, Davidson WS (1998) Purification and characterization of a regiospecific lipase from Aspergillus terreus. Biotechnol Appl Biochem 28:243-249 